\title{
Parents' Guidance Resources during the Identification Process for the Gifted and Talented Students at the Şanlıurfa BILLSEM
}

\author{
Arif Belur ${ }^{1}$, Nagihan Oğuz-Duran ${ }^{2, *}$ \\ ${ }^{1}$ Lyon Consulate, France \\ ${ }^{2}$ Faculty of Education, Department of Educational Sciences, Uludag University, Turkey
}

Copyright $\bigcirc 2017$ by authors, all rights reserved. Authors agree that this article remains permanently open access under the terms of the Creative Commons Attribution License 4.0 International License

\begin{abstract}
The purpose of this study is to investigate the guidance resources for parents whose children participated in the identification procedures for the gifted and talented students (GT), and as a result either did or did not qualified to enroll the Science and Art Center (BİLSEM) in Şanliurfa, Turkey. With this purpose, a four-part survey developed by the researchers was carried out with a total of 261 parents whose children were qualified to enroll (PQE) or not qualified to enroll (PNQE) the BILLSEM. Socio-demographic findings revealed that both groups of parents of all the students who participated in the identification process had a high level of education; but, the PQE higher income and have fewer children than the PNQE. Results on parents' guidance sources and experiences indicated that the source the PQE received the most support at all stages of the identification procedure was class teachers. A third of the parents were involved in the identification procedures either with little or no information. The vast majority of parents stated that they did not benefit from school counseling. Furthermore, it was found that the rate of parents' benefiting from the provisions of other experts' mental health services were limited. Parents who used the school counseling services or the services of other experts reported that assistance was insufficient.
\end{abstract}

Keywords Gifted and Talented, Parents, Guidance Resources, Science and Art Center (BILSEM)

\section{Introduction}

Most countries, in a competitive world, regard gifted and talented (GT) individuals as important resources because an individual who is creative, knowledgeable, and who has a different perspective, has the potential to make a difference. In this case, the training and employment of GT individuals is important to prevent brain drain. For this very purpose, the
Turkish Ministry of National Education (MONE) founded the Science and Art Centers (BILSEMs) to serve the scientific and artistic needs of GT students in Turkey.

BİLSEMs are public, educational institutions that attract the attention of GT students. These centers serve under the MONE General Directorate of Special Education Guidance and Counseling Services. GT students are accepted to BILLSEMs by a three-step assessment system. In the first step, primary class teachers make observations and use rating scales to determine their potentially GT students. At this step, all the primary school students $\left(1^{\text {st }}, 2^{\text {nd }}, 3^{\text {rd }}\right.$, and $4^{\text {th- }}$ year students) around the country are scanned via the use of an "observation form" to refer students for further testing. In the second step, selected students take group intelligence tests. Finally, based on the results of this test, at the final stage, successful students take the individual intelligence test (Weschler Intelligence Scale for Children -WISC-R). The students identified as GT and selected for BILSEMs receive project-based training in line with their interests and needs at times outside of their formal education. That is, students continue to attend their regular schools and participate in selected programs at the BILSEM. A pullout enrichment program is applied at BILSEMs. Education at these institutions consists of five stages as follows: orientation, supporting education, discovery of personal talents, development of special talents, and project generation. As of 2016, the number of BILLSEMs in Turkey, the first of which opened in 1995 , reached $80[1,2,3]$.

It is frequently emphasized in the literature that students identified as GT, i.e., those selected for BILLSEMs in Turkey, require specialized counseling and guidance services because of their group-specific qualifications $[4,5,6]$. This support should start from the beginning of the GT identification process; it should continue during and after the identification procedure, and generally throughout the educational life of the GT students. In parallel, parents of GT students need to be supported by guidance services both 
at the schools and at the BILSEMs in the same way that the GT students need to be supported.

In the relevant literature, there are many studies about the various characteristics of GT students, their teachers, and the institutions that serve them or the training programs applied to them. Moreover, in many of the articles and theses about GT children, there are suggestions for their families [7, 8]. However, it is not possible to say that the studies regarding the families of GT students in Turkey, particularly concerning their counseling and guidance needs, have reached a sufficient level [9-14]. A limited number of studies conducted on this subject inquired into the subjects on which subjects the families of GT children generally needed information, with what resources they met these needs, and whether they differed according to the education level of the parents, the education level of the children and whether they were mothers and fathers $[12,13]$. In addition, in two experimental studies, the effectiveness of face-to-face [14] and remotely [11] applied training programs for the families of GT students were tested. However, when it comes to the identification procedures, it is seen that the experiences and needs of the families of the students who have come out of the process in question, having been identified as GT or otherwise, have never been investigated in any study in Turkey.

The process of identifying GT students is an important step that requires both guidance services support for all students involved in this process as well as their parents. Once entered into the identification process, it is clear that whether or not the students are identified as GT individuals will have various effects on the students involved and their families at the end of this process. At the end of the identification process, in light of the outcome reported to them about their children, parents whose children are identified as GT must wait for support, but parents whose children have not been identified as GT (children of different strengths) also require support and advice [15]. Suarez [15] points out that while the parents of the students identified as GT were focused on the parents of the students who participated in the identification process but were not identified, as GT were not appropriately focused on in the relevant literature. For this purpose, he developed a five-session therapeutic module and used it with the latter group of parents. This intervention aimed to minimize the psychological difficulties that these parents could experience. The program was found to be effective. For Turkey, identifying the guidance needs of the parents of children who have participated in the identification process, and who were or were not identified as GT, is also important. This kind of needs assessment will contribute to the development of models and intervention methods for both groups of identified and not-identified students.

From the point of view of school guidance and counseling services, according to the American Association of School Counselors, school counselors are the key players in meeting the needs of the GT students in their schools. School counselors have been assigned an important role in the school environment, as an advocate and a voice that contributes to the fairness of education and success [cited in 16]. Accordingly, it is important for school counselors to increase the awareness and knowledge of the guidance needs of parents of all children participating in the GT identification process, and to provide more effective intervention and education opportunities for these children and their families.

\subsection{The Present Study}

In the present study, the parents whose children participated in the GT identification process at the Şanlıurfa BILSEM were examined in terms of their experiences in this process. For this purpose, responses were sought for the following research questions.

1. What are the various socio-demographic characteristics of the parents of students who participated in the identification process?

2. What are the experiences of the parents throughout the identification process?

3. What are the sources from which the parents get help for their guidance needs? If they get help, what is their level of satisfaction with this help?

\section{Method}

\subsection{Research Design}

The present study is a survey research study based on parents' self-reported data. Some socio-demographic characteristics of the parents of children who participated in the BILSEM GT identification process, their experiences throughout the identification process the resources they received to help with their guidance needs, and their level of satisfaction with this help were determined through the opinions the parents stated.

\subsection{Population and Sampling}

This study was carried out on the parents of students who participated in the BILSEM GT student identification process in the Şanliurfa province during the data collection phase of academic year 2012-2013, who completed all three steps (teacher referring, group screening test, and individual identification process), and who were accepted or rejected by this institution. Sanliurfa BILSEM was selected for investigation, since the first author was working at this province as a school counselor while this study was conducted. Şanliurfa BILSEM was the only BILSEM at this province.

All sampling procedures were reviewed and approved by the Institutional Review Board of Uludağ University and the Turkish Ministry of Education, Şanlıurfa province. All 
the parents of the students were contacted through the students' schools. First, the researchers compiled a list of schools where the students had the highest number of applications for the BİLSEM identification process in the Şanlıurfa province. Then, with the approval and support of the MONE and the school administrations, and with the help of the school counselors, research instruments were given to the students who participated in the BILSEM identification procedures to pass on to their parents. A total of 261 parents who volunteered to participate in the study constituted the sample of the research; this was from the parents of a total of 1100 students who participated in the GT identification process in the 2011 and 2012 academic years. Only one of each student's parents was included in the study. The fathers constituted nearly $56 \%$ of the sample $(n=147)$ and the mothers $44 \%(n=114)$. It was stated by the officials interviewed in the Şanlıurfa BILLSEM that there were originally 30 students who qualified for enrollment but two of the students moved to another city with their families. All the parents of the students enrolled at the Şanliurfa BİLSEM $(n=25)$ were contacted. The parents of three students that did not attend BILLSEM, even though they had the right to enroll, were also contacted during the practices in the schools. Accordingly, the parents of a total of 28 students $(42.90 \%$ female, $57.10 \%$ male) who qualified for enrollment were contacted. When the number of enrolled students was subtracted from the total number of students enrolled in that year's identification process $(1100-30=$ 1070), the number of students who did not qualify for enrollment was obtained; 415 of those parents in the survey were contacted. The number of returned questionnaires was 293, 32 of which were invalid because of incomplete data. The number of valid questionnaires filled in by the parents was 233 . Accordingly, nearly $22 \%$ of the study universe consisting of the parents of the students who qualified for enrollment in the study was contacted.

\subsection{Data Gathering Instrument}

The researchers developed the survey instrument used in the research. In the development of the questionnaire form, the relevant literature was reviewed for the guidance needs of GT students and their families [1 $0,17-26]$, and a draft form consisting of four sections was created. This draft form was reviewed by two faculty members from the Department of Counseling and a counseling doctoral student who took part in the process of identifying GT students. The revised version was applied to two parents whose children participated in the BİLSEM identification process in that year. This review focused on the clarity, scope, and content of the items in the questionnaire.

The first part of the questionnaire aimed to identify some of the socio-demographic characteristics of the families. This section in the questionnaire included open and closed-ended questions about the gender, age, educational status, educational status of the spouse of the person who filled in it, monthly income of the family, and the number of children in the family.

In the second part of the questionnaire, there were questions aimed at dividing the participants of the study into two groups: "parents of children who qualified for enrollment" (PQE) and "parents of children who did not qualify for enrollment" (PNQE).

The third part of the questionnaire consisted of questions about the parents' experiences during the BİLSEM identification process. This section consisted of closed and open-ended questions concerning parents' sources of information, which sources the parents were most likely to benefit from during the different stages of the GT student identification process, and whether there were changes in the behavior of the family and the school towards the child following the test results. A question was prepared in the form of a five-point Likert-type, and it aimed to determine the extent to which the parents were satisfied with the support they received from the various resources during the application phase.

The fourth part of the questionnaire aimed to identify the "guidance needs" that the participants, as parents, felt so far about their children who participated in the identification process, and the parents' "sources of support" about their guidance needs, and whether they were satisfied with the support they received. The "Guidance needs" section consisted of a total of 39 five-point Likert-type items with four sub-dimensions (Academic, Social, Psychological and Opportunities Provided by the Family), which was written on the basis of the relevant literature [6, 10, 16-32, 33]. The option of the open-ended "other" was also added to the end of these items. Cronbach-Alpha $(\alpha)$ coefficients that were calculated for this part of the questionnaire ranged from .743 to .890 . Scale/subscale intercorrelations were also examined for this part, and the four sub-dimensions were found to be significantly correlated with the total score and each other. However, since the results of the "Guidance needs" section of the scale is beyond the focus of the present study, these results, along with the data gathered by this part of the questionnaire, were not presented.

The final section of part four aimed to determine the parents' "sources of support" concerning their guidance needs, and whether they were satisfied with the support they received. This section included the Likert-type and closed-ended questions about the parents' application status to the school counselor, the level of their satisfaction with the school counselor, and any other experts that the parents received help from and the extent to which they were satisfied with this help. Open-ended space was provided for the participants at the end of the questionnaire for any opinions and recommendations they wished to express.

\subsection{Data Collection / Procedure}

The first author collected the data by going to the schools. The questionnaires were distributed in sealed envelopes to 
the students who participated in the identification process to be given to their parents. The delivery and collection of the questionnaires to the parents who volunteered to participate in the study was completed in March and April of 2013.

\subsection{Data Analysis}

In the analysis of the data, in addition to descriptive statistics such as mean $(X)$, standard deviation (Sd), frequencies (f) and percentages (\%), two-way ANOVA was used. The significance level was accepted as .05. The SPSS 17.0 was used in analyzing the data.

\section{Findings}

\subsection{Findings about the Socio-Demographic Characteristics of the Parents}

In the study, primarily the frequencies and percentages of various socio-demographic characteristics of the parents who filled in the questionnaire (gender, age, educational status, income level and number of children in the family) were calculated separately for the PQE and PNQE. Results are presented in Table 1. Accordingly, more than half of the participants in the study were the fathers of the participating children. When the parents' decimal age-range groups were examined, it was observed that the majority of participants were in the 36-45 age group. The PQE and PNQE had a similar distribution in terms of age group. Furthermore, when the mean of the ages of the parents participating in the study were calculated for the three groups (PQE, PNQE, and total) these values were $38.77(\mathrm{Sd}=7.60), 38.26(\mathrm{Sd}=5.93)$ and $38.31(\mathrm{Sd}=6.09)$, respectively.

Table 1. Some Socio-demographic Characteristics of Parents

\begin{tabular}{|c|c|c|c|c|c|c|}
\hline & \multicolumn{2}{|c|}{ PQE } & \multicolumn{2}{c|}{ PNQE } & \multicolumn{2}{c|}{ Total } \\
\hline Variable & $\mathrm{f}$ & $\%$ & $\mathrm{f}$ & $\%$ & $\mathrm{f}$ & $\%$ \\
\hline Gender & & & & & & \\
\hline Female & 10 & 35.71 & 104 & 44.63 & 114 & 43.67 \\
\hline Male & 18 & 64.28 & 129 & 55.36 & 147 & 56.32 \\
\hline Age & & & & & & \\
\hline 25 \& below & - & - & 1 & .42 & 1 & .38 \\
\hline $26-35$ & 10 & 35.71 & 82 & 35.19 & 92 & 35.24 \\
\hline $36-45$ & 15 & 53.57 & 119 & 51.07 & 134 & 51.34 \\
\hline $46-55$ & 2 & 7.14 & 27 & 11.58 & 29 & 11.11 \\
\hline $56 \&$ above & 1 & 3.57 & - & - & 1 & .38 \\
\hline Unanswered & - & - & 4 & 1.71 & 4 & 1.53 \\
\hline $\begin{array}{c}\text { Number of } \\
\text { children }\end{array}$ & & & & & & \\
\hline 1 & 2 & 7.10 & 14 & 6.01 & 16 & 6.10 \\
\hline 2 & 12 & 42.90 & 80 & 34.33 & 92 & 35.20 \\
\hline 3 & 11 & 39.30 & 80 & 34.33 & 91 & 34.90 \\
\hline 4 \& above & 3 & 10.70 & 59 & 25.32 & 62 & 23.80 \\
\hline
\end{tabular}

With regard to number of children in the family, according to Table 1 , the majority of the parents had $2 / 3$ children in their families. The number of PQE with a single child, two children, and three children was higher than for the PNQE. With regard to percentages, $\mathrm{PQE}$ exceed the percentage of PNQE for one, two, and three children. Only in the case of four and more children does the percentage of PNQE exceed that of PQE, and PQE families exceed the PNQE families at three categories. Therefore, this finding of the present study is not consistent with the findings of previous studies which indicated that the parents of GT individuals had fewer children [34-35].

After that, the distribution of the educational status of the parents in the study was first examined for the parents who filled in the questionnaire, and then for their non-respondent spouses. The results are presented in Table 2 and Table 3, respectively. Accordingly, nearly half (51\%) of the parents participating in the survey were university graduates, and nearly a quarter $(26 \%)$ was high school graduates. The rate of the PQE with a university degree $(64.28 \%$ ) was higher than both their non-participating partner $(50 \%)$ and the PNQE $(48.92 \%)$. The rate of high school and postgraduate graduate parents was higher among PNQEs than the PQEs for the respondent parents. However, considering the total number of university degree and postgraduate degrees of PQEs (the total of both participating and non-participating parents), PQEs $(64.28+3.57=67.85 \%$ for participating parents, and $50+3.57=53.57 \%$ for non-participating parents) seem to had a higher level of education than the PNQEs (48.92+ $6.43=55.35 \%$ for participating parents, and $36.90+.6 .43=$ $43.33 \%)$, consisting with the earlier literature $[10,12,26$, 36-39].

Finally, the socio-economic levels of the parents in the study were examined in terms of the responses the parents provided to the open-ended question regarding the common income of the family. The average monthly income of the participating families was calculated as $3017 \mathrm{TL}$; this average was $3285 \mathrm{TL}$ for the PQE, and $2975 \mathrm{TL}$ for the PNQE. Hence, it is possible to say that the group composed of the PQE was slightly wealthier or economically had more advantages than the other group.

Table 2. Educational Status of Parents who Respond to the Questionnaire

\begin{tabular}{|c|c|c|c|c|c|c|}
\hline & & PQE & \multicolumn{2}{|c|}{ PNQE } & \multicolumn{2}{c|}{ Total } \\
\hline $\begin{array}{c}\text { Educational } \\
\text { Status }\end{array}$ & $\mathrm{f}$ & $\%$ & $\mathrm{f}$ & $\%$ & $\mathrm{f}$ & $\%$ \\
\hline 1 & - & - & - & - & - & - \\
\hline 2 & - & - & 1 & .42 & 1 & .38 \\
\hline 3 & 1 & 3.57 & 21 & 9.01 & 22 & 8.42 \\
\hline 4 & 3 & 10.71 & 19 & 8.15 & 22 & 8.42 \\
\hline 5 & 5 & 17.85 & 62 & 26.60 & 67 & 25.67 \\
\hline 6 & 18 & 64.28 & 114 & 48.92 & 132 & 50.57 \\
\hline 7 & 1 & 3.57 & 15 & 6.43 & 16 & 6.13 \\
\hline 8 & - & - & 1 & .42 & 1 & .38 \\
\hline Total & 28 & 99.98 & 233 & 99,85 & 261 & 99.97 \\
\hline
\end{tabular}

(1) Non-literate, (2) Literate without degree, (3) Elementary School degree, (4) Secondary School degree, (5) High School degree, (6) University degree, (7) Postgraduate degree, (8) Unanswered 
Table 3. Educational Status of Parents who did not Respond to the Questionnaire

\begin{tabular}{|c|c|c|c|c|c|c|}
\hline & \multicolumn{2}{|c|}{ PQE } & \multicolumn{2}{c|}{ PNQE } & \multicolumn{2}{c|}{ Total } \\
\hline $\begin{array}{c}\text { Educational } \\
\text { Status }\end{array}$ & $\mathrm{f}$ & $\%$ & $\mathrm{f}$ & $\%$ & $\mathrm{f}$ & $\%$ \\
\hline 1 & - & - & 7 & 3 & 7 & 2.68 \\
\hline 2 & - & - & 6 & 2.58 & 6 & 2.29 \\
\hline 3 & 4 & 14.29 & 29 & 12.44 & 33 & 12.64 \\
\hline 4 & 2 & 7.14 & 25 & 10.73 & 27 & 10.34 \\
\hline 5 & 7 & 25 & 64 & 27.47 & 71 & 27.20 \\
\hline 6 & 14 & 50 & 86 & 36.91 & 100 & 38.31 \\
\hline 7 & 1 & 3.57 & 15 & 6.44 & 16 & 6.15 \\
\hline 8 & - & - & 1 & .43 & 1 & .38 \\
\hline Total & 28 & 100 & 233 & 100 & 261 & 100 \\
\hline
\end{tabular}

(1) Non-literate, (2) Literate without degree, (3) Elementary School degree, (4) Secondary School degree, (5) High School degree, (6) University degree, (7) Postgraduate degree, (8) Unanswered

\subsection{Findings about the Parents' Experiences during the Identification Process}

For the second question of the study, data were collected regarding the sufficiency of the level of information parents had at the beginning of the identification process; the sources of information that they made use of the most during the application, testing and results learning phases; the information sources that they used the most in the process application, taking the test and learning the test results stages; whether the parents observed any changes in the behavior of the family and the school towards the child after learning the test results, and what these changes were, if any.

The findings on the views of parents concerning how much information the parents they managed to obtain from various sources in the application phase are presented in Table 4 .

Table 4. Opinions of the Parents on the Sufficiency of their Level of Information at the Application Stage

\begin{tabular}{|l|c|c|c|c|c|c|}
\hline \multirow{2}{*}{$\begin{array}{c}\text { Level of } \\
\text { Satisfaction }\end{array}$} & \multicolumn{2}{|c|}{$\mathrm{PQE}$} & \multicolumn{2}{c|}{ PNQE } & \multicolumn{2}{c|}{ Total } \\
\cline { 2 - 7 } & $\mathrm{f}$ & $\%$ & $\mathrm{f}$ & $\%$ & $\mathrm{f}$ & $\%$ \\
\hline Fully Informed & 8 & 28.57 & 29 & 12.45 & 37 & 14.18 \\
\hline Well Informed & 7 & 25.00 & 35 & 15.02 & 42 & 16.09 \\
\hline Partly Informed & 9 & 32.15 & 77 & 33.05 & 86 & 32.95 \\
\hline $\begin{array}{l}\text { Insufficiently } \\
\text { Informed }\end{array}$ & 2 & 7.14 & 47 & 20.17 & 49 & 18.77 \\
\hline $\begin{array}{l}\text { Involved in the } \\
\text { process } \\
\text { without prior } \\
\text { information }\end{array}$ & 2 & 7.14 & 43 & 18.45 & 45 & 17.24 \\
\hline Unanswered & - & - & 2 & 0.86 & 2 & 0.77 \\
\hline \multicolumn{1}{|c|}{ Total } & 28 & 100 & 233 & 100 & 261 & 100 \\
\hline
\end{tabular}

As seen in Table 4, nearly one-third (32.95\%) of the parents reported that they were partly informed. The fact that $17.24 \%$ of the participants stated that they were involved in the process without any prior information can be seen as important data, as it reflects the idea that the parents did not receive any support rather than whether they were satisfied with it. Furthermore, when the sum of the rates of those who obtained various grades of information between "fully informed" and "partly informed" was examined, the level of PQE who had sufficient knowledge at the beginning of the whole process seemed to be higher $(85.7 \%)$ than for the other group $(60.5 \%)$.

The sources that parents used to get information during the three stages of the identification process are presented in Tables 5, 6, and 7, respectively. Accordingly, as seen in Table 5, when the sources of information utilized the most during the application stage are examined, it is seen that the parents made use of the class teachers the most, and other resources were far behind the class teachers for both the PQE and the PNQE. However, it is also noticeable that BILSEM $(25 \%)$ was the second most utilized source for the PQE. Although BILSEM was unlikely to be of benefit during the application phase, the fact that the PQE used this particular resource or information, either through their own efforts or due to the fact that their children were already enrolled when the data of this study were collected, it is possible to think that PQE parents made substantial use of BILLSEM. A remarkable proportion of parents, especially the PNQE $(47.21 \%)$, did not answer this question.

Table 5. Sources of the Parents during Application Stage

\begin{tabular}{|l|c|c|c|c|}
\hline \multirow{2}{*}{ Sources } & \multicolumn{2}{|c|}{ PQE } & \multicolumn{2}{c|}{ PNQE } \\
\cline { 2 - 5 } & $\mathrm{f}$ & $\%$ & $\mathrm{f}$ & $\%$ \\
\hline Class teacher & 18 & 64.28 & 104 & 44.63 \\
\hline BİLSEM & 7 & 25 & 1 & .42 \\
\hline Friend/s & 1 & 3.57 & 4 & 1.71 \\
\hline Family members & - & - & 4 & 1.71 \\
\hline Internet-web & - & - & 2 & 0.84 \\
\hline Parents of other GT & - & - & 1 & .42 \\
\hline School Management & - & - & 4 & 1.71 \\
\hline School guidance services & - & - & 2 & .84 \\
\hline Radio-TV & - & - & 1 & .42 \\
\hline $\begin{array}{l}\text { Guidance and Research } \\
\text { Center of the Province }\end{array}$ & - & - & - & - \\
\hline $\begin{array}{l}\text { Books, Articles, } \\
\text { Publications }\end{array}$ & - & - & - & - \\
\hline Other sources & - & - & - & - \\
\hline Unanswered & 2 & 7.14 & 110 & 47.21 \\
\hline Total & 28 & 100 & 233 & 100 \\
\hline
\end{tabular}

With regards to the sources that the parents used the most during and after the test taking stages, Tables 6 and 7 present very similar findings in regard to that, in both of these stages, the sources that the parents used the most were their children's classroom teacher and BILLSEM. However, the order of the most used sources seems to be changed according to the phases of the identification process. While 
in the test taking stage, the most used resource was the class teacher for the PQE, this source replaced with the BILSEM during the learning the results stage. Comparing the PQE and the PNQE in the two stages of the process, in the PQE group, while the support from BILSEM was the highest after the test taking stage, it was revealed that the class teachers were the number one source of information for the PNQE in both of the test taking and learning the results stages. Additionally, it is interesting to note that for both groups of parents at all three stages of the identification process (application, test taking, and learning the results), the rate of the parents who did not answer the question was very high. Being unwilling to answer these questions seems more prevalent among the PNQE than the PQE in all three stages. For Tables 5, 6, and 7, the high rates of unanswered questions might have resulted for several reasons. For instance, although there was an "other" option in the questionnaire, there was not a "none" option. Therefore, parents who did not use any of these sources, or did not seek any support, might have passed over this question. Alternatively, respondent parents might have suffered from survey fatigue at this stage of the study. These limitations of the data gathering instrument of the present study should be considered in further studies, as it will be discussed in the discussion section. Moreover, an additional question to consider might be whether the PNQE group felt any commitment to answer these questions since their children had not been accepted into the program.

This study also revealed findings regarding whether there was any difference in the behavior of the family members after learning the test results. The opinions and observations of the participating parents are presented in Table 8.

Table 6. Sources of the Parents during Test Taking Stage

\begin{tabular}{|l|c|c|c|c|}
\hline \multirow{2}{*}{ Sources } & \multicolumn{2}{|c|}{ PQE } & \multicolumn{2}{c|}{ PNQE } \\
\cline { 2 - 5 } & $\mathrm{f}$ & $\%$ & $\mathrm{f}$ & $\%$ \\
\hline Class teacher & 12 & 42.85 & 49 & 21.03 \\
\hline BİLSEM & 7 & 25 & 12 & 5.15 \\
\hline Friend/s & 1 & 3.57 & 2 & .85 \\
\hline Family members & 1 & 3.57 & 6 & 2.57 \\
\hline Internet-web & - & - & 3 & 1.28 \\
\hline Parents of other GT & 1 & 3.57 & 1 & .42 \\
\hline School Management & - & - & 7 & 3.00 \\
\hline School guidance services & - & - & 4 & 1.71 \\
\hline Radio-TV & - & - & - & - \\
\hline $\begin{array}{l}\text { Guidance and Research } \\
\text { Center of the Province }\end{array}$ & 1 & 3.57 & 5 & 2.14 \\
\hline $\begin{array}{l}\text { Books, Articles, } \\
\text { Publications }\end{array}$ & - & - & 2 & .85 \\
\hline Other sources & - & - & - & - \\
\hline Unanswered & 5 & 17.85 & 142 & 60.95 \\
\hline Total & 28 & 100 & 233 & 100 \\
\hline
\end{tabular}

Table 7. Sources of the Parents during Learning the Results Stage

\begin{tabular}{|l|c|c|c|c|}
\hline \multirow{2}{*}{ Sources } & \multicolumn{2}{|c|}{ PQE } & \multicolumn{2}{c|}{ PNQE } \\
\cline { 2 - 5 } & $\mathrm{f}$ & $\%$ & $\mathrm{f}$ & $\%$ \\
\hline Class teacher & 6 & 21.42 & 42 & 18.02 \\
\hline BiLSEM & 16 & 57.14 & 5 & 2.14 \\
\hline Friend/s & 1 & 3.57 & 2 & .85 \\
\hline Family members & - & - & 6 & 2.57 \\
\hline Internet-web & - & - & 4 & 1.71 \\
\hline Parents of other GT & - & - & - & - \\
\hline School Management & - & - & 4 & 1.71 \\
\hline School guidance services & 2 & 7.14 & 9 & 3.86 \\
\hline Radio-TV & - & - & - & - \\
\hline $\begin{array}{l}\text { Guidance and Research } \\
\text { Center of the Province }\end{array}$ & - & - & - & - \\
\hline $\begin{array}{l}\text { Books, Articles, } \\
\text { Publications }\end{array}$ & - & - & 2 & .85 \\
\hline Other sources & - & - & - & - \\
\hline Unanswered & 3 & 10.71 & 159 & 68.24 \\
\hline Total & 28 & 100 & 233 & 100 \\
\hline
\end{tabular}

Table 8. Parents' Views on whether There was a Change in Behaviors towards the Child in the Family after Taking the Test Results

\begin{tabular}{|l|c|c|c|c|c|c|}
\hline \multirow{2}{*}{ Groups } & \multicolumn{2}{|c|}{ Yes } & \multicolumn{2}{c|}{ No } & \multicolumn{2}{c|}{ Total } \\
\cline { 2 - 7 } & $\mathrm{f}$ & $\%$ & $\mathrm{f}$ & $\%$ & $\mathrm{f}$ & $\%$ \\
\hline PQE & 13 & 46.43 & 15 & 53.57 & 28 & 100 \\
\hline PNQE & 21 & 9.01 & 212 & 90.98 & 233 & 100 \\
\hline Total & 34 & 13.03 & 227 & 86.97 & 261 & 100 \\
\hline
\end{tabular}

According to Table 8, it was reported that following the period when the test results were learned, there were more changes of behavior towards their children among the PQE than the PNQE. Nearly half $(46 \%)$ of the PQE stated that upon learning the test results, there was a change in behavior within the family towards their children, whereas a lower amount of PNQE (9.01\%) reported behavior changes toward their children. When parents were asked to explain these changes in an open-ended question in the questionnaire, the number of responses to this item was found to be very low for both parent groups. Only 5 out of 28 parents (approximately $18 \%$ ) from the PQE group and only 7 out of 233 PNQE parents $(3 \%)$ responded. The proportion of the PQE who are willing to answer to the question seems higher than the proportion of the PNQE. Among the answers were statements including: "an increase in admiration, appreciation" and "increase in showing interest within the family", "more pamper" and "take it more seriously" from the PQE; whereas the PNQE stated, "increase in showing interest within the family", "increase in being more active for the child", "more respect", "sibling jealousy", and "despondency". However, since there were no more than two responses to any item, this data does not need to be shown in a separate table. 
The findings, according to the parents, related to behavioral changes in schools towards the participating students in the identification processes after learning the test results are presented in Table 9.

Table 9. Parents' Views on Changes in Behavior in the School after Learning the Test Results

\begin{tabular}{|c|c|c|c|c|c|c|}
\hline \multirow{2}{*}{ Groups } & \multicolumn{2}{|c|}{ Yes } & \multicolumn{2}{c|}{ No } & \multicolumn{2}{c|}{ Total } \\
\cline { 2 - 7 } & $\mathrm{f}$ & $\%$ & $\mathrm{f}$ & $\%$ & $\mathrm{f}$ & $\%$ \\
\hline PQE & 13 & 46.43 & 15 & 53.57 & 28 & 100 \\
\hline PNQE & 17 & 7.29 & 216 & 92.70 & 233 & 100 \\
\hline Total & 30 & 11.49 & 231 & 88.50 & 261 & 100 \\
\hline
\end{tabular}

Table 9 shows that nearly half of the PQE (46.43\%) stated that there was a change towards their child in schools after the identification process. According to their parents, the students who qualified to enroll encountered more changed behavior in school in comparison to those students who did not qualify. Similar to the previous question, when parents were asked to explain these changes in an open-ended question in the questionnaire, the number of responses to this item was found to be very low for both parent groups. Only 7 out of 28 parents from the PQE group, and only 6 out of 233 PNQE responded. However, this proportion represents $25 \%$ of the PQE group and half of the PQE who reported any change. Therefore, once more, the proportion of the PQE who are willing to answer to the question seems higher than the proportion of the PNQE. Among the answers were: "Began to be envied by friends", "friends' point of view and expectations differed", "more attention and importance started to be given". Additionally, PQE reported, "attract the attention of other parents", whereas PNQE reported, "teacher felt sorry", and "they were surprised". However, since there were no more than three responses to any item, this data does not need to be shown in a separate table. The finding of the present study about the changes in behavior in the school toward the students participated in the GT identification process and labeled as GT is consistent with the previous literature. According to Suarez [15] children will receive additional support in the public school when they are labeled as gifted, however, the effects the label has on those who are participated to the identification process but do not received the GT label was not investigated previously.

\subsection{The Findings about the Sources of Support for the Parents' Guidance Needs and the Level of their Perceived Satisfaction with this Help}

In order to find an answer to the third research question, data were collected about the parents' application to the school counselor, their level of satisfaction with the service they received, whether they received services from other experts, which other experts they received help from, and their level of satisfaction with services they received from other experts. The findings regarding the status of parents' applications to the school counselor for their children who were involved in the identification process are presented in Table 10 . Approximately $51 \%$ of the parents did not apply to the school counselor because they did not have the problems mentioned in the questionnaire; further, 35\% said that they had some problems, but they did not ask for any help from the school counselor; nearly $12 \%$ asked for help from the school counselor for some problems they experienced, and as little as $1 \%$ said they asked for help from the school counselor for all their problems. It is understood that the majority of the parents $(86 \%)$ did not apply to the school counselor, either because they did not need it (51\%) or because they still did not apply, even if they needed it $(35 \%)$. Although there seemed to be a similarity between the PQE and PNQE, it can be said that the rate of those parents who asked for help from the school counselor was higher among the PQE. Nearly $13 \%$ of the participating parents and about $21 \%$ of the PQE in the study asked for help from the school counselor. This rate was $12 \%$ for the PNQE.

Table 10. Status of Participating Parents application to the School Counselor Asking for Help

\begin{tabular}{|c|c|c|c|c|c|c|}
\hline \multirow{2}{*}{$\begin{array}{c}\text { Request for } \\
\text { Help }\end{array}$} & \multicolumn{2}{|c|}{ PQE } & \multicolumn{2}{c|}{ PNQE } & \multicolumn{2}{c|}{ Total } \\
\cline { 2 - 7 } & $\mathrm{f}$ & $\%$ & $\mathrm{f}$ & $\%$ & $\mathrm{f}$ & $\%$ \\
\hline 1 & 13 & 46.43 & 120 & 51.50 & 133 & 50.95 \\
\hline 2 & 7 & 25.00 & 85 & 36.48 & 92 & 35.24 \\
\hline 3 & 5 & 17.86 & 26 & 11.15 & 31 & 11.87 \\
\hline 4 & 1 & 3.57 & 2 & 0.85 & 3 & 1.15 \\
\hline 5 & 2 & 7.14 & - & - & 2 & 0.76 \\
\hline Total & 28 & 100 & 233 & 100 & 261 & 100 \\
\hline
\end{tabular}

(1) We never applied to the school counselor because our child did not have any of the problems above; (2) Our child had some problems, but we never asked for help from the school counselor; (3) We asked for help some of our problems from the school counselor; (4) We asked for help for all our problems from the school counselor, (5) Unanswered.

The findings on the extent to which the parents who received services from the school counselor were satisfied with it are presented in Table 11.

Table 11. Opinions of the Parents on the Adequacy of the Help They Received from the School Counselors

\begin{tabular}{|c|c|c|c|c|c|c|}
\hline \multirow{2}{*}{$\begin{array}{c}\text { Level of } \\
\text { satisfaction }\end{array}$} & \multicolumn{2}{|c|}{ PQE } & \multicolumn{2}{c|}{ PNQE } & \multicolumn{2}{c|}{ Total } \\
\cline { 2 - 7 } & $\mathrm{f}$ & $\%$ & $\mathrm{f}$ & $\%$ & $\mathrm{f}$ & $\%$ \\
\hline Fully satisfied & - & - & 1 & 3.57 & 1 & 2.94 \\
\hline Quite satisfied & 3 & 50 & 6 & 21.43 & 9 & 26.47 \\
\hline Partly satisfied & 3 & 50 & 12 & 42.86 & 15 & 44.12 \\
\hline Little satisfied & - & - & 5 & 17.86 & 5 & 14.71 \\
\hline Never satisfied & - & - & 4 & 14.28 & 4 & 11.76 \\
\hline Total & 6 & 100 & 28 & 100 & 34 & 100 \\
\hline
\end{tabular}

According to Table 11, half of the PQE who received help from the school counselor were "quite satisfied", and the other half of that group were "partly satisfied" with this help. "Little satisfied" and "Never satisfied" options were only reported by the PNQE group: the total percentage for these 
answers was $32.14 \%$, whereas the total for the "fully", "quite", and "partly satisfied" options was $67.86 \%$. Therefore, it is possible to say that the PQE were more satisfied with the service they received than the PNQE. Alternatively, the PNQE group was comparatively very dissatisfied, with $32 \%$ having "little satisfaction" or less, compared with zero percent of PQE in the same categories.

The findings of the study on the status of the parents' application to an expert other than the school counselor (psychiatrist, psychologist, BİLSEM's counselor and other expert/s) to get services about the children participating in the identification process are presented in Table 12. Additionally, Table 13 illustrates the data for other experts to whom the parents applied for help on the issues related to their children, even though there were very few.

Table 12. Status of the Parents'Application to other Experts other than School Counselor

\begin{tabular}{|c|c|c|c|c|c|c|}
\hline \multirow{2}{*}{} & \multicolumn{2}{|c|}{ PQE } & \multicolumn{2}{c|}{ PNQE } & \multicolumn{2}{c|}{ Total } \\
\cline { 2 - 7 } & $\mathrm{f}$ & $\%$ & $\mathrm{f}$ & $\%$ & $\mathrm{f}$ & $\%$ \\
\hline Yes & 4 & 14.28 & 18 & 7.72 & 22 & 8.42 \\
\hline No & 23 & 82.14 & 212 & 90.98 & 235 & 90.03 \\
\hline Unanswered & 1 & 3.57 & 3 & 1.28 & 4 & 1.53 \\
\hline Total & 28 & 100 & 233 & 100 & 261 & 100 \\
\hline
\end{tabular}

Table 13. Other Experts the Parents Applied to Help other than the School Counselor

\begin{tabular}{|l|c|c|c|c|c|c|}
\hline \multirow{2}{*}{ Expert } & \multicolumn{2}{|c|}{ PQE } & \multicolumn{2}{c|}{ PNQE } & \multicolumn{2}{c|}{ Total } \\
\cline { 2 - 7 } & $\mathrm{f}$ & $\%$ & $\mathrm{f}$ & $\%$ & $\mathrm{f}$ & $\%$ \\
\hline Psychiatrist & - & - & 8 & 3.43 & 8 & 3.06 \\
\hline Psychologist & 1 & 3.6 & 6 & 2.57 & 7 & 2.70 \\
\hline $\begin{array}{l}\text { BİLSEM's } \\
\text { Counselor }\end{array}$ & 2 & 7.15 & 2 & 0.86 & 4 & 1.53 \\
\hline Other & - & - & 3 & 1.29 & 3 & 1.15 \\
\hline Unanswered & 25 & 89.79 & 214 & 91.84 & 239 & 91.57 \\
\hline Total & 28 & 100 & 233 & 100 & 261 & 100 \\
\hline
\end{tabular}

Considering Tables 12 and 13 together, the PQE seemed to be in a better position to receive special guidance and counseling services from the school counselor than the PNQE. However, the PNQE seemed to apply to a wider range of sources than the PQE. While school counselors, psychologists, and BILSEM's own counselor were the experts the PQE applied to on the issues related to their children, in addition to these three experts, PNQE also applied to psychiatrists and other experts (pediatrician and teacher, both of which are not mental health personnel). However, it should be noted that the number of parents who made use of the BİLSEM's psychological counseling services was lower than expected. Although previously, especially the PQE reported they used BILSEM as a primary resource both at the test taking and learning the results stages of the GT identification process, it seems that their main source in BILSEM was not the counselor of the center.

Finally, the last question of the study was about the parents' satisfaction with the services they received from "other experts". However, due to the low number of parents who applied to experts other than the school counselor $(\mathrm{N}=3$ for $\mathrm{PQE}$, and $\mathrm{N}=19$ for PNQE) these results are not given in separate tables. Although with such low response rates it seems not possible to drawn useful conclusions, according to the answers given by the parents regarding the level of the service they received, it was seen that $37.5 \%$ of the PNQE who applied to a psychiatrist were "never", 25\% were "very little", 25\% were "partially" (25\%), and 12.5\% were "fully" satisfied. No PQE applied to a psychiatrist. While the PQE reported that $\mathrm{s} /$ he was "partially" satisfied with the help $\mathrm{s} / \mathrm{he}$ received from the psychologist, $67 \%$ of the PNQE were "partially" and 33\% "never satisfied" with the service. Hence, it is possible to interpret that the majority of the parents who applied for help from both a psychiatrist and a psychologist found that they were "very little" satisfied with the help they received. While half of the parents who received help from the BILSEM's psychological counselor reported that they were "fully satisfied" with the help received, the other half reported that they were "partially satisfied" with it. In this sense, it is possible to say that that the level of satisfaction of parents who applied to BILLSEM counseling services with the help they received was higher than for the other experts.

\section{Discussion}

\subsection{Discussion about the Socio-Demographic Characteristics of the Parents}

Most of the parents who participated in this study were fathers. While it was seen that the female rate of participants in the previous studies [10, 12, 26, 36-37] was higher than the males, there were few studies [39] in which the rate of male participants was higher. In this regard, while it was found that most of the previous studies had a higher proportion of women than of men, the studies in which the proportion of men was higher were also available. This particular situation is explained in the relevant literature by the fact that the mothers of GT children were more willing to participate in the studies, and that they were more interested in their children's education than their fathers. Similarly, in western literature, mothers are reported as being more involved in their children's education and educational activities [40-41]. In the present study, the finding that more fathers answered the questionnaire was likely to be explained by the influence of the social and cultural environment on the roles of men and women. This was because the city of Şanlıurfa, where the research was conducted, is located in the southeastern part and on the Syrian border of Turkey. In this region, a patriarchal culture was more dominant, whereby men had more rights to speak out and were more enterprising [42].

The average age of the parents in the study group was very close to one another; it was 38 years old for the parents of the 
students in both groups who qualified and did not qualify for enrollment at BİLSEM. This was consistent with the findings of previous studies [26, 36-37], which demonstrated that GT children were born after their parents were beyond their $20 \mathrm{~s}$.

The findings related to the education levels of the families in the study showed that both groups of parents had a high level of education, regardless of whether or not their children did or did not qualify for enrollment. The findings about the high education levels of parents of the GT children are consistent with those of previous studies, which indicated that the parents of GT individuals had a high level of education [10, 12, 26, 36-39]. However, in the present study, the number of PNQEs who held postgraduate degrees exceeded those of the PQE. This may be due to the fact that families with high educational levels increase the educational opportunities for their children, or that their education levels make them more aware of the education of their children. These opportunities might make their children candidates for the GT identification process.

The findings regarding the economic status of the families demonstrated that families of students who participated in the identification process were mostly middle-income and wealthy families; in addition, the PQE were wealthier than the PNQE. This particular finding is compatible with the findings of studies $[10,26,36]$, which concluded that the families of GT children were mostly middle-income and wealthy families. Finally, it was found that the majority of the families participating in this study had $2 / 3$ children. The parents with four or more children were more common among the PNQE. Since in the case of four and more children does the percentage of PNQE exceed that of PQE, it is consistent with the relevant literature which indicated that the parents of GT individuals had fewer children [34-35]. This can be explained by the fact that parents of GT children may limit the number of children that they have because they are somewhat more educated and wealthier. However, in the present study, PQE families exceed the PNQE families at the other three categories. Once more the cultural characteristic of the region might have an effect on the results, since it is common to have many children in this part of the country. Childbirth is a guarantee of the social status of both women and men in this region. For this reason, more educated and wealthy families may still be interested in having more than one child even though they have limited the number of children they will have [42].

\subsection{Discussion about the Parents' Experiences during the Identification Process}

In this study, when the adequacy level of the resources that the participating parents made use of during the application phase were compared, it was found that the adequacy level of the PQE was higher than the PNQE. Another important finding of the study was the fact that participants indicated that one-fifth of the parents entered the process of identification without any information. Hence, it was revealed that there is a need for the school management and school guidance and counseling services to increase, or make more effective, activities in terms of informing and guiding the parents during the application process.

Additionally, in the present study, the families reported classroom teachers to be an important source and support during all the phases of the identification process of GT individuals. While the PQE reported classroom teachers as the most important source during the first two phases and as the second important source at the third phase of the process, the PNQE reported classroom teacher as the most important source at all three phases. This demonstrates the importance of ensuring that classroom teachers need to be more informed about the GT individual characteristics and the process of identification. The fact that classroom teachers were the most utilized source at almost every stage was a phenomenon [24] that was also found in the findings of previous studies. It is believed that the reason for this is explained primarily by the important role that class teachers played on the students and parents, since the students who participated in the identification process were primary school students (in the school year when this study was conducted, $2^{\text {nd }}$ year students were included in the GT identification process). Moreover, the fact that these teachers carefully screened the status of the students they nominated as potentially being GT and established an effective parental relationship, might also affect this particular result. However, if the guidance and counseling services were to be more active in the application, testing, learning the test result stages and regarding the general situation of their students, they might make such a process less distressing for the students and parents. Additionally, according to the findings of this study, as the identification process progressed, BİLSEM became one of the most important sources for the PQE; this particular situation might easily be explained by the increase of the ties of the parents with BILLSEM.

In this study, when the parents were asked about the changes in behavior in the family and the school towards the children after learning the test results, a small percentage of the parents (the total group) answered it positively saying "yes". However, it was found that nearly half of the PQE for BILSEM indicated a change in behavior towards their children within the family and at the school. This result may be due to the fact that the students who successfully qualified to enroll at BILSEM had more rewarding experiences at the end of the identification process. It was seen that in the PNQE, on the other hand, the change in behavior towards their children in the family and at the schools of the children was found to be very low. However, it should be remembered that the answers given to this question were the subjective evaluations of the parents.

Although in the present study, the nature of some behavioral changes that occurred within the family and school towards the child at the end of the GT individual identification process was specified by some parents, as the number of parents who answered this question was very low, 
it is not possible to consider this data as significant or to discuss these findings. Interestingly, a very high rate of unanswered questions was seen in this part of the study. As noted previously in the findings section, the high rate of unanswered questions might result from several reasons such as the lack of a "none of these sources" option in the questionnaire, or a survey fatigue that the respondents might have suffered at this stage of the study. Additionally, parents might be unwilling to answer open-ended written questions such as the questions asked in this study about the "changes in the behavior towards the child in the family after learning the identification test results" and "changes in the behavior towards the child in the school after learning the identification test results". Considering these limitations of the present study, further studies may use alternative data collection techniques such as interviews or shorter survey instruments.

\subsection{Discussion about the Sources of Help for the Parents' Guidance Needs and the Level of Their Perceived Satisfaction with this Help}

According to the findings of this study, only a small percentage of the parents whose children participated in the BILSEM identification process asked for help from the school counselor with their child's problems. It is clearly seen that the PQE received more help from the school counselor than the PNQE. This can be related to the level of education, awareness and needs of the group in question. Moreover, it is seen that most parents who received help from the school counselor found the services they received "partially" satisfactory. In this case, the lack of full satisfaction is a note of caution for the effectiveness of the school guidance and counseling services. It was also found that PQE were more satisfied with the services they received than the PNQE. Failure to qualify does not mean that the participating children and their families need less guidance and counseling support. These children and their families continue to need guidance and counseling, just like those who qualified for enrollment. The fact that they were not satisfied with the support is important in terms of the fact that the school guidance and counseling services need to increase their awareness, and services to meet the needs of this group.

Some of the parents who participated in the study stated that they applied to experts for help other than the school counselor. The rate of parents who applied to other experts was higher among the PQE. The rate of PQEs asking for help from the school counselor, and from other experts, shows that the PQE group made efforts to seek and ask for more help than the PNQE However, the PNQE group who sought help pursued a wider range of sources than the PQE. This finding is consistent with the previous research which revealed that parents tend to use more informal sources before seeking professional expert help [43]. Because, in the present study, although parents seem to be willing to use formal sources of help (such as counselors, psychiatrists, and psychologists) as well, the number of parents who seek for expert assistance is only about half of the families in the whole group. Moreover, those parents who seek expert assistance seem mostly "partly" or "little" satisfied with the services they received.

\subsection{Limitations of the Study}

Some limitations of the present study should be noted in the interpretation and generalization of the findings. The first limitation concerns the study sample. This study was carried out with parents whose children participated in the GT identification process at the Şanlıurfa BILSEM. In order to reflect the general Turkish parents of GT students who attended the GT identification processes, further research could include parents from other regions of Turkey, as well.

Secondly, this study relied on self-reported data. Further research might benefit from the use of alternative measurements, such as the use of observational data to examine parents' actual resources. For instance, data gathered from school and/or BILSEM counseling services may provide detailed information regarding the parents' guidance needs, and their use of these resources before, during and after the identification processes.

Finally, as previously mentioned in the findings section, a high number of unanswered questions were seen in the present study. Alternative explanations for this situation listed as; (1) the lack of a "none" option in the data collection instrument, (2) parents' possible suffering from survey fatigue because of the number of items of the instrument, (3) parents' unwillingness to answer open-ended written questions such as the questions asked in this study about the "changes in the behavior towards the child in the family after learning the identification test results" and "changes in the behavior towards the child in the school after learning the identification test results", and (4) the PNQEs possible low commitment to answer the questions, because of their children's non-acceptance to the program. Using a shorter instrument could be recommended for further studies to attain a better understanding of the experiences of parents whose children attending to the identification process. Additionally, further research might benefit from the use of qualitative inquiry, such as in-depth interviews with parents. By this way, it could be possible to make the parents (both the PQE and the PNQE) more motivated to share their experiences during the process, and as a result learn more about their needs, emotions, and experiences.

\section{Conclusions}

To conclude, participating in the GT identification process, whether the child has or has not been identified as a GT individual at the end, will generate some results that will affect different areas a child's development throughout their 
lives. Classroom teachers and mental health professionals such as school counselors, BILSEM counselors, psychiatrists, and psychologist should provide support services for the parents of students (and the students) who participate in GT identification processes. The fact that guidance and counseling professionals and services have not taken on a competent role in a process that could have such crucial consequences in one's life draws attention to an important shortcoming in the area.

\section{REFERENCES}

[1] MEB. 2016-2017 Bilim ve Sanat Merkezleri Öğrenci Tanilama Kilavuzu. https://orgm.meb.gov.tr/meb_iys_dosyalar/2016_10/1109390 1_bilim_ve_sanat_merkezleri 20162017 kilavuzu.pdf

[2] B. Sezginsoy-Seker, An Evaluation on Science-art Center Implementation through the BILSEM Teachers' Opinion. Social and Behavioral Sciences, Vol. 46, 1628-1632, 2012.

[3] F. Şahin, Educational Programs, Services and Support for Gifted Students in Turkey. Journal of Theory and Practice in Education, Vol. 11, No: 4, 1207-1223, 2015.

[4] R.M. Milgram, Counseling Gifted and Talented Children: A Guide for Teachers, Counselors, and Parents. New Jersey: Ablex Publishing, 1991.

[5] L.K. Silverman, Counseling the Gifted and Talented. Denver: Love Publishing Company, 1993.

[6] J. E. Yoo \& S. M. Moon, Counseling Needs of Gifted Students: An Analysis of Intake Forms at a University-Based Counseling Center. Gifted Child Quarterly., Vol. 50, No. $1, .52-61,2006$.

[7] D.F. Dettmann, \& N.A. Colangelo. A Functional Model for Counseling Parents of Gifted Students. Gifted Child Quarterly, 24, 158-161, 1980.

[8] C.F. Lester \& R.S. Anderson. Counseling with Families of Gifted Children: The School Counselor's Role, The School Counselor, Vol. 29, No.12, 147-151, 1981.

[9] U. Davaslıgil, Üstün Çocuklara Sahip Ailelerin Eğitimi [The Education of the Parents of Gifted and Talented Children] T.C. Milli Eğitim Bakanlığı Özel Eğitim Rehberlik ve Danışma Hizmetleri Genel Müdürlüğü. Özel Eğitimde Aile Eğitimi Sempozyumu, 142-148, 2000.

[10] F. Karakuş, Üstün Yetenekli Çocukların Anne Babalarının Karşılaştıkları Güçlükler [Difficulties that Families of Gifted Students Face]. Mersin Üniversitesi Eğitim Fakültesi Dergisi,[Mersin University Journal of the Faculty of Education] 6-1, 127-144, 2010.

[11] M. Z., Leana-Tascilar, M. Ozyaprak, \& O. Yilmaz, An Online Training Program for Gifted Children's Parents in Turkey. Eurasian Journal of Educational Research, Vol. 65, 147-164 10.14689/ejer.2016.65.09, 2016.

[12] Ü. Oğurlu \&, Y. Yaman, Guidance Needs of Gifted and Talented Children's Parents. Turkish Journal of Giftedness and Education, Vol. 3, No. 2, 81-94, 2013.
[13] H. Öztop, Anne ve Babaların Ebeveyn Eğitimine İlişkin Bilgi İhtiyacının Belirlenmesi [An Investigation of the Parents' Needs of Parenetal Education]. Hacettepe Üniversitesi. Sağlık Bilimleri Enstitüsü. Bilim Uzmanlığı Tezi, Ankara, 1994.

[14] A. G. Saranlı \& E. N. Metin Saranl1, SENG Üstün Yetenekliler Aile Eğitimi Modelinin Üstün Yetenekli Çocuklar ve Ailelerine Etkileri [The Effects of the SENG Gifted and Talented Family Education Model on Gifted Children's Families]. Eğitim ve Bilim, Vol, 39, No. 175, 1-13, 2014.

[15] B. Suarez, A Therapeutic Module Designed to be Delivered to Parents Whose Children were Recently not Accepted into the Gifted Program. Widener University. School of Human Service Professions. Unpublished Doctoral Dissertation, 2008 .

[16] S. Wood, Gifted and Talented Adolescents' Experiences in School Counseling. The College of William \& Mary. School Of Education. Department of Counselor Education. Unpublished Doctoral Dissertation, 2006.

[17] K. E. Ablard \& W. D. Parker, Parents' Achievement Goals and Perfectionism in Their Academically Talented Children. Journal of Youth \& Adolescence. December, Vol.26, No.6, 651-667, 1997.

[18] İ. Akar, İlköğretim Kademesindeki Üstün Yetenekli Öğrencilerin Rehberlik Gereksinimlerinin Ebeveynlerinin ve Öğretmenlerinin Görüşlerine Dayalı Olarak Belirlenmesi [Determination of the Primary School Gifted and Talented Students' Guidance Needs Based on Their Parents' and Teachers' Views]. Anadolu Üniversitesi. Eğitim Bilimleri Enstitüsü. Yayınlanmamış Yüksek Lisans Tezi [Unpublished Master Dissertation]. Eskişehir, 2010.

[19] F. Akarsu, Üstün Yetenekli Çocukların Ailelerinin Sorunları [Problems of the Families of Gifted and Talented Children]. Üstün Yetenekli Çocuklar Seçilmiş Makaleler [Selected Papers on Gifted Children]. İstanbul, Çocuk Vakfı Yayınları. 448-458, 2004.

[20] J. Freeman, The Psychology of Gifted Children: Perspectives on Development and Education. Great Britain. John Wiley and Sons, 1985.

[21] L. S. Hollingsworth, Children Above 180 IQ Stanford Binet: Origin and Development. New York: World Book., 1942.

[22] G.T. Betts \& M. Neihart, Profiles of the Gifted and Talented. Gifted Child Quarterly, Vol. 32, No:2, 248-253, 1988.

[23] M. Neihart,. Services that Meet Social and Emotional Needs of Gifted Children. In J. H. Purcell \& R. D. Eckert (Eds.), Designing Services and Programs for High Ability Learners: A Guidebook for Gifted Education. California: Corwin Press. 2006.

[24] L. Novatna, \& J. Sejvalová. Education of the Gifted in the Czech Republic. Development of Human Potential: Investment into Our Future (Eds. Mönks, F. J. \& Wagner, H.). ECHA. 2002

[25] L. K. Silverman, \& K. Kearney, Parents of the Extraordinarily Gifted. Advanced Development Journal. Vol. 1, 41-56, January, 1989.

[26] L. A. Wingers, Parents' Help Seeking During The Gifted İdentification Process: Formal and Informal Sources of Support. Capella University. Harold Abel School of Social and 
Behavioral Sciences. Unpublished Doctoral Dissertation, 2011.

[27] N. N. Carlson, School Counselors' Knowledge, Perceptions And İnvolvement Concerning Gifted And Talented Students. Maryland University, Unpublished Doctoral Dissertation, 2004.

[28] N. Colangelo \& ,D. F. Dettmann, A Rewiew of Research on Parents and Families of Gifted Children. Exceptional Children, Vol. 50, 20-27, 1983.

[29] J. J. Levy \& J. A. Plucker, Assessing the Psychological Presentation Gifted and Talented Clients: A Multicultural Perspective. Counseling Psychology Quarterly, Vol. 16, No. 3, 229-247, 2003.

[30] Ü. Oğurlu,. Üstün Zekâlı ve Yeteneklilerde Sosyal uyum ve Arkadaşlık İlişkileri: Literatür Taraması. [Social Adjustment and Friendship in Gifted and Talented: A Literature Review]. Cukurova Üniversitesi Eğitim Fakültesi Dergisi [Cukurova University Journal of the Faculty of Education], Vol. 3, No. $39,90-99,2010$

[31] F. M. Pradeille, L'accompagnement de la Famille par le Médecin Généraliste, de la Découverte de la Précocité Intellectuelle Chez L'enfant en Difficulté Scolaire à la Mise en Place de Solutions. Université de Picardie Jules Verne. Faculté de Médecine. Unpublished Doctoral Dissertation, 2012.

[32] S. Wood, Best Practices in Counseling the Gifted in Schools: What's Really Happening? The Gifted Child Quarterly, Vol. $54,42-58,2010$

[33] B. Bourdeau, \& V. Thomas, Counseling Gifted Clients and Their Families: Comparing Clients' and Counselors' Perspectives. Journal of Secondary Gifted Education, Vol. 14, No. 2, 114-126, 2003

[34] H.E. Dağlioğlu, \& S. Suveren, The Role of Teacher and Family Opinions in Identifying Gifted Kindergarten Children and the Consistence of these Views with Children's Actual Performance. Educational Sciences: Theory \& Practice, Vol. 13, No. 1, 444-453, 2013.

[35] H. Y1ldız, Üstün Yeteneklilerin Eğitiminde Bir Model Olan Bilim ve Sanat Merkezleri Üzerine Bir Araștırma. Gazi Üniversitesi. Eğitim Bilimleri Enstitüsü. Eğitim Bilimleri Anabilim Dalı. Eğitimin Sosyal ve Tarihi Temelleri Programı. Yayınlanmamıs Yüksek Lisans Tezi. Ankara., 2010.
[36] A.B. Ataman, Üstün Yetenekli Çocuklarda Aile Ortamının Bazı Demografik Değişkenler Açısından İncelenmesi: İstanbul BİLSEM Örneği. [Study of the Family Environment of Gifted Children in Relation to Some Demographic Variables Perspectives: The Case of İstanbul BILSEM] Yeditepe Üniversitesi. Sosyal Bilimler Enstitüsü. Eğitim Yönetimi ve Denetimi Yüksek Lisans Program. Yayınlanmamıs Yüksek Lisans Tezi, İstanbul, 2008.

[37] N. Özkan, Üstün Zekâl1-Üstün Yetenekli Çocukların Eğitiminde Okulun, Öğretmenin ve Ailenin Yeri [The Role of School, Teacher, and Family on Gifted Children's Education]. Beykent Üniversitesi. Sosyal Bilimler Enstitüsü. İşletme Yönetimi Ana Bilim Dalı. Eğitim Yönetimi ve Denetimi Bilim Dal1. Yayınlanmamış Yüksek Lisans Tezi, İstanbul , 2009.

[38] S. Bencik, Üstün Yetenekli Çocuklarda Mükemmeliyetçilik ve Benlik Algisı Arasındaki İlişkinin İncelenmesi [An Investigation of the Relationship between Perfectionism and Self-Concept among Gifted and Talented Students]. Hacettepe Üniversitesi. Sağllk Bilimleri Enstitüsü. Cocuk Gelișimi ve Eğitimi Programı. Yayınlanmamış Yüksek Lisans Tezi, Ankara, 2006.

[39] E. Öpengin, Üstün Zekâlı Öğrencilerin Bakıș Açısıyla Üstün Zekâ Etiketinin Öğrencilerin Çeşitli Algıları Üzerindeki Etkileri [Effects of Labeling Students as Gifted According to Gifted Students' Perceptions]. Anadolu Üniversitesi. Eğitim Bilimleri Enstitüsü. Özel Eğitim Ana Bilim Dalı. Yayınlanmamış Yüksek Lisans Tezi, Eskişehir, 2011.

[40] N., Colangelo, S. Assouline, I. Chen, \& T. Tsai, Parental Involvement in the Academic and Social Lives of Academically Talented Elementary School Students. Talent Development: Proceedings from the 1995 H.B. and Jocelyn Wallace National Research Symposium on Talent Development, pp. 307-311; Great Potential Press, Inc, 1999.

[41] D. Reay, .Class Work: Mothers' Involvement in Their Children's Primary Schooling. London: UCL Press, 1998.

[42] Ş.Ökten, Gender and Power: The System of Gender in Southeastern Anatolia. The Journal of International Social Research, Vol. 2, No. 8, 302-312, 2009.

[43] A., Raviv, K., Sharvit, A., Raviv, \& S. Rosenblat-Stein, Mothers' and Fathers' Reluctance to Seek Psychological Help for Their Children. Journal of Child and Family Studies, Vol. 18, No. 2, 151-159. 2009. 